\title{
International Organisations and the Global Environment
}

\author{
Hannes R. Stephan \& Fariborz Zelli ${ }^{1}$
}

\section{Introduction}

The organisational network of global environmental governance (GEG) mirrors the complexity of the planet's manifold and overlapping ecosystems. Bursting onto the international stage in the 1970s, environmental issues began to be addressed by a series of new international organisations, most of them affiliated with the United Nations. Some of them, such as the United Nations Environment Programme (UNEP), were given a broad mandate, whereas others like the World Meteorological Organisation (WMO) concentrated on a much more precise issue-area and have gained significant authority for their respective subfields. After the end of the Cold War, the rise of international environmental organisations has continued unabated. Yet the new institutions came to life in an already institutionalised context: some of the urgent tasks of management and coordination had already been allocated, and the newcomers often contributed to a growing trend towards organisational fragmentation.

For this chapter, we have adopted a broad and inclusive definition of international organisation that is nonetheless distinguished from two other types of international institutions, namely what Keohane (1989: 4) describes as institutions with explicit rules (international regimes) and institutions with implicit rules ("conventions"). In contrast, the organisations we study are bureaucratic actors and "purposive entities" which are "capable of monitoring activity and of reacting to it" and have been "deliberately set up and designed by states" (ibid: 3). They include not only fully-fledged 'organisations', but also UN commissions and programmes. Among the plethora of organisations with environment-related activities, we have restricted our analysis to those operating at the global level and have further selected those with either a clear environmental profile or a significant impact on global environmental governance.

In addition to our leitmotif of organisational fragmentation - which evokes the image of a mosaic of institutional elements - we have also taken account of current debates over mainstreaming and sectoralisation. Thus, many of the organisations reviewed in this chapter contain indications of the progress made towards a greater cross-sectoral integration of environmental concerns. For instance, the World Bank or the United Nations Development Programme (UNDP) now routinely address environmental factors in their decision-making, albeit with variable sincerity. Such insights feed into our concluding analysis of future trends and perspectives for reforming the system of global environmental organisations. We begin our survey by describing a number of well-known global environmental conferences which provided the seedbed for the steady expansion of international environmental activities.

\footnotetext{
${ }^{1}$ Both authors contributed equally to this chapter.
} 


\section{United Nations-sponsored Global Environmental Conferences}

International organisations neither emerge from nor exist in a political vacuum and they commonly rely on national governments' support for the negotiation and implementation of environmental agreements. However, the UN system, which accommodates the key globally operating environmental organisations, is clearly more than a simple 'tool' of its members; in particular, the institutions or fora it initiates at times count as significant actors in their own right. As Bennett and Oliver (2002: 25-26) have observed, "[i]f environmental sensibilities and regulation have developed, the discourse that has produced them has occurred within a diplomatic and legal framework set by UN commissions and conferences over the last thirtyodd years." The progressive accumulation of norms, principles and action plans - commonly interpreted as elements of non-binding 'soft' law - began with the UN Conference on the Human Environment (UNCHE) at Stockholm in 1972. Despite concerns from the developing world about potential implications for economic development (Imber 1996), the summit mostly dealt with 'first-generation' environmental problems such as point-source pollution. Apart from the creation of UNEP, Stockholm produced a detailed action plan of environmental measures, a political declaration of 26 principles, and gave a genuine impetus to national policy-makers, often leading to the formation of national environmental ministries (Chasek 2000: 3).

By 1992, when Stockholm's successor - the UN Conference on Environment and Development (UNCED) - was convened, the bipolar world had just come to an end. Optimism and a thirst for action were palpable at the 'Earth Summit' in Rio de Janeiro and such feelings were not limited to the growing number of environmental NGOs that had come as observers. "[G]lobal environmental change", ventures Vogler (2007: 435), had "in some ways replaced fears of nuclear Armageddon". On a substantive level, the forceful emphasis of the global South on development issues, already visible in Stockholm, had left a deep imprint on the international agenda. Seeking to integrate the demands of environmental protection and socio-economic progress, the concept of sustainable development - popularised by the Brundtland Report in 1987 - arguably embodied the "central ideology of UNCED" (Imber 1996: 139) and it pervaded the 27 principles contained in the Rio Declaration. In addition, negotiators produced the Agenda 21, a 700-page non-binding action plan (Chasek 2000: 4) that has since continued to guide environmental policy-making at all governmental levels. The Commission on Sustainable Development (CSD) was tasked with reviewing the progress towards its goals. Finally, UNCED also created treaties on climate change and on biodiversity which spawned several important protocols in the ensuing years - the most famous being the Kyoto Protocol. With hindsight, UNCED's two major environmental conventions marked a shift towards greater governmental control, for the secretariats of these newcomers could not match the relative independence of some earlier global environmental conventions, such as the 1973 Convention on International Trade in Endangered Species (CITES). 
When the World Summit on Sustainable Development (WSSD) at Johannesburg went underway in the summer of 2002, much of Rio's idealism had been exhausted. Developing countries were buoyed by the rising prominence of the UN's Millennium Development Goals (MDGs). The developed world, on the other hand, was affected by public apathy and increasing tension over both trade and environmental policies between the USA and the European Union. Talk of a new mobilising idea - a 'global deal' between the global North and South - was quickly abandoned in favour of finding practical ways of implementing previous, unachieved commitments through "isolated delivery mechanisms" (Bigg 2003). More emphasis than before was placed on public-private 'type 2' partnerships with a view to supplementing official development aid (ODA), but this was not matched by a binding code for corporate responsibility. The topics of trade and poverty eradication arguably stole the limelight from the title theme of sustainable development and reduced environmental considerations to a restatement of existing agreements (von Frantzius 2004). A political declaration and the Johannesburg Plan of Implementation (JPI) contained over 30 targets on both development and environmental issues, yet specific instruments for implementation were largely absent (ibid: 472).

Overall, given the limited achievements of the WSSD, there is an unmistakable impression of 'summit fatigue' among both political actors and academic commentators. If the grand 'show-biz' diplomacy of global summits is clearly flagging, it may be worth looking at the myriad ways in which the wider "UN environmental machinery" (DeSombre 2006) has sought to tackle global environmental issues. One of the bodies set up to provide a more continuous organisational effort is the UN Commission on Sustainable Development.

\section{Commission on Sustainable Development (CSD)}

A brainchild of UNCED, the CSD began its life with high expectations. Steeped in the 'spirit of Rio' and entrusted with the global pursuit of sustainable development, the new body's primary objective was to provide a follow-up to the summit's priorities and review the implementation of Agenda 21. The CSD is constituted by 53 member states which serve three-year terms. Its status as a functional commission of the Economic and Social Council (ECOSOC) does not endow it with specific powers or significant resources. Instead, it seeks to assist the sustainable development agenda by making recommendations to the UN system (by reporting to ECOSOC), monitoring national reports on implementation, and organising multi-stakeholder dialogues with major interest groups and government representatives. This systematic inclusion of civil society organisations is illustrated by a long list of accredited observers (3000 in November 2001), among them hundreds of NGOs (Wagner 2005: 105).

The crucial question to ask is whether the CSD has lived up to the hopes of its creators and whether its continued existence can be justified. Despite some patently useful work on freshwater or forests, influential ideas or a significant policy impact have not been among its achievements. Its recommendations often resemble restatements of decisions made in other international fora and the underlying assumption that "if they talk about it, they will 
implement it" has proved to be unfounded (ibid: 118). Furthermore, over the years, the CSD's agenda had become increasingly crowded and this frequently prevented a thorough discussion on the various propositions.

Serious engagement with civil society organisations is the major innovation consistently mentioned by commentators. Yet, in the absence of a clear policy focus there have been successive attempts at improving the Commission's performance. The 1997 reform of the CSD tried to streamline the agenda and remove some overlap with other UN fora, but only the improvements made after the 2002 WSSD review have brought about visible change. The CSD now observes a bi-annual negotiation cycle, with preparatory meetings in between remaining in a kind of "exploratory" mode (ibid: 112). Whilst the leaner agenda and more modest ambition of 'facilitating' political and technical 'learning' have removed some overlap with other UN organisations (e.g. UNEP), it has not led to a 'rebirth' of the CSD as a major co-ordinator in the environmental field. Overall, its recent de-politicisation - achieved through a greater emphasis on expert meetings and problem-solving in collaboration with industry groups and NGOs - has made the CSD a constructive, yet unobtrusive addition to the UN's environmental machinery. The modest ambition behind the revamped CSD stands in marked contrast with the hopes invested in a strengthening of UNEP.

\section{United Nations Environment Programme (UNEP)}

\section{History}

UNEP is rightly seen as the core of environmental activities within the UN system. Its 35-year long history has been marked by a series of crises, notable achievements, and re-orientations. A product of the 1972 Stockholm Conference and the UN General Assembly's Resolution 2997, the new agency (first headed by Maurice Strong) was essentially modelled on the United Nations Development Programme (UNDP). This arrangement was intended to match the "interdisciplinary and complex nature of environmental problems" and accommodate a "vast catalogue of recommended actions" (Thomas 2004: 57-59). From the beginning, governments recognised the cross-cutting nature of environmental problems. UNEP's status as programme rather than fully-fledged agency should thus not be read as a sign of early disregard or subordination (Ivanova 2005: 32).

This form of organisation, however, also meant that UNEP's resources were being spread thinly across a whole range of issues. The Programme's role as the UN's environmental conscience - both coordinating and catalysing global environmental activities - resulted in a broad selection of seven priority areas: human settlements and habitats (later turned into UN Habitat), human and environmental health, terrestrial ecosystems, environment and development, oceans, energy, and natural disasters (Downie and Levy 2000: 356). Following 'muscular' but contested attempts at system-wide environmental coordination in the 1970s, UNEP came into its own in the early 1980s when it instituted the 'Programme for the Development and Periodic Review of Environmental Law', also known as the 'Montevideo 
Programme'. This decision cemented UNEP's role in catalysing and developing international environmental law.

During the same period, UNEP was nevertheless becoming marginalised in other areas of environmental policy-making. The formation of the World Commission on Environment and Development (WCED) appropriated much of its normative power and unique environmental mandate (Conca 1995). In response, UNEP produced the report 'Environmental Perspectives to the Year 2000 and Beyond' which proved to be an important influence on the 1992 Earth Summit in Rio de Janeiro (WRI 2003: 143). The conference itself, however, was not an unmitigated blessing for UNEP. It certainly ushered in a series of budget increases, but it also broadened the agency's remit once again and agreed on the formation of the CSD. The availability of such alternative fora exacerbated the ensuing crisis in the mid-1990s (Wagner 2005). Elizabeth Dowdeswell, who replaced the long-time Executive Director Mostafa Tolba in 1992, presided over a period in which many countries were losing confidence in UNEP's capability. Its ambitious System-Wide Medium-Term Environment Programme (SWMTEP 1990-1995) was regarded as a "meaningless checklist" or a device for 'turf-grabbing' by many UN officials (Thomas 2004: 88). In 1997, matters came to a head when the USA, Britain, and Spain linked continued financial support to significant organisational reform (Karns and Mingst 2004: 476). The 1997 Nairobi Declaration broke the spell of decline and gave UNEP, headed by Klaus Töpfer from 1998-2006, a new lease of life. The new dynamism was further strengthened by the 2000 Malmö Declaration of environmental ministers - meeting as the Global Ministerial Environmental Forum (GMEF) for the first time - who sent out a strong message of concern in the run-up to the 2002 WSSD.

In the new millennium, UNEP has been a highly visible component of GEG once again, not least due to a stabilising budget and the debate over an upgrading of its status. Its fifth Executive Director Achim Steiner, who took office in June 2006, lauded his predecessor Töpfer for helping to "stabilize the organisation and expand its operations" and pledged to continue on the basis of this legacy (UNEP 2007: 3).

\section{Structure and Activities}

The Governing Council (GC) reviews UNEP's progress and establishes its specific priorities. As UNEP is a Programme under the aegis of the Economic and Social Council (ECOSOC), the GC is expected to report to it directly. The GC's 58 members are elected for four-year terms by the UN General Assembly according to a regional formula. ${ }^{2}$ The members meet annually and their decisions are best described as the driving force of UNEP's overall legal and operational activities. This does not, however, always translate into a clear or consistent framework of priorities because member states often insist on their own preferred projects (Ivanova 2005: 22). During the remainder of the annual cycle, the Committee of Permanent Representatives (CPR), located in Nairobi, provides political guidance and monitoring. The

\footnotetext{
${ }^{2}$ Africa (16 seats), Asia (13), Eastern Europe (6), Latin America and Caribbean (10), Western Europe and others
} (13) 
organisational trinity is completed by the GMEF which has been convened since 2000 and is tasked with giving UNEP a stronger, long-term programmatic direction and political leadership.

The day-to-day running of the organisation is the business of the UNEP Secretariat in Kenya's capital Nairobi and six regional offices around the world. UNEP has a comparatively small professional staff of just over 900 employees. Its annual budget is dwarfed by sister agencies like UNDP and reaches about \$260 million. ${ }^{3}$ The annual core, 'non-earmarked' funding (known as the Environmental Fund) has been hovering at just below $\$ 60$ million during the past few years. Not having the capacity or funds of a genuine delivering agency, UNEP needs partnerships with NGOs and other international organisations if it wants to go beyond catalysing and administrating international environmental law (Conca 1995). For instance, cooperative projects have been conducted with the World Meteorological Organisation (WMO) on the atmosphere or with the Food and Agriculture Organisation (FAO) and the World Health Organisation (WHO) on freshwater quality (Karns and Mingst 2004).

Overall, as Thomas (2004: 18) suggests, UNEP's activities can be summarised by the "four 'C's" of compiling, convincing, catalysing, and coordinating. The task of compilation is related to the agency's original mission of representing a clearinghouse for environmental data and research at a time when such efforts were still in their infancy. Under a programme named 'Earthwatch', UNEP began to coordinate observation techniques and data analysis among all UN agencies as early as 1973. Through various dissemination mechanisms, such as the Global Environmental Information Exchange Network (INFOTERRA), the Global Environmental Monitoring System (GEMS), and its annual flagship publication 'Global Environmental Outlook' (GEO), it has sought to maximise the impact of its scientific analyses. The second brief - convincing the world to take action - is closely linked to the vexed question of effectiveness, which is discussed below. Besides its scientific authority and management expertise, UNEP's "most basic skill" is diplomacy (Thomas 2004: 31). As a vital ingredient in the catalytic role which has seen the agency assume the mantle of a leader or broker in particular negotiations it determines the success or failure of attempts at mainstreaming new concepts. In this respect, it is worth recalling that UNEP had taken up the notion of 'sustainable development' in the early 1980s - even before it was popularised by the WCED in 1987.

Finally, UNEP's coordination mandate is generally seen as a disappointment. A succession of inter-agency bodies have been entrusted with the objective of achieving more system-wide programmatic coherence and with mainstreaming environmental goals. The latest incarnation, the Environment Management Group (EMG), has the unambitious task of

\footnotetext{
${ }^{3}$ These figures are based on a personal communication from UNEP and refer to its own statistics from 31 December 2005. The annual budget includes all sources of funding, demonstrating the importance of ear-marked funds if compared with the size of the Environment Fund.
} 
identifying synergies in the UN system and commands only a minuscule resource base (Ivanova 2005: 29).

\section{Evaluation}

The ineffectiveness of UNEP's "Sisyphean" coordination mandate (Imber 1996) appears to imply a negative judgement on its general performance. In what some writers consider a 'feudal' UN system with a weak centre and strong 'baronial' independent agencies (ibid: 150), UNEP is continually emasculated and does not even have nominal authority over the environmental conventions it has helped to set up. Fruitful collaboration is surely a regular occurrence, but the idea of coordination assumes direct guidance from a lead agency. Frequently, however, UNEP represents a mere adjunct to existing projects: for instance, in providing organisational functions to particular multilateral environmental agreements (MEAs) or by acting as a scientific advisor to the dominant partners (World Bank, UNDP) in the Global Environment Facility (GEF). Its subdued status has been weakened further by the creation of alternative fora, such as the CSD in 1992, and its politically desirable, but impractical location in Kenya - far away from the 'corridor politics' of UN hot spots in New York or Geneva.

Of course, there are also more promising findings about UNEP's performance, in particular with regard to its catalytic functions. The agency has excelled in its roles as "agreement facilitator", "negotiation manager", and "regime administrator" (Downie 1995: 176). In line with the standard functions of international organisations, it has scheduled meetings at a propitious time and generated negotiation procedures that have helped the quest for compromise solutions. Moreover, it has occasionally entered the debate as a capable actor itself: during the negotiations on ozone depletion UNEP's Executive Director Mostafa Tolba abandoned the appearance of impartiality and began to refer to "UNEP's interests". He judiciously used UNEP's organisational powers and scientific knowledge to push for an adequate international agreement (D'Anieri 1995: 165-66). Finally, the case of the Regional Seas Programmes illustrates the possibility of overall leadership responsibility. Six of the thirteen Regional Seas projects are directly administered by UNEP and have been reliant on its diplomatic skill and scientific argumentation as well as on a constant stream of funding (DeSombre 2006).

Yet a thorough assessment of the programmes' results yields a picture that is symptomatic of UNEP's general record over the last decades: marked environmental improvement is difficult to ascertain, even if the measures agreed have surely helped to slow the pace of deterioration. "[U]seful but not dramatic work" (DeSombre 2006: 19) may well be a fitting description of both the Regional Seas Programmes and UNEP's impact on the wider area of global environmental governance. More joint planning and activities with its sister agency UNDP would arguably enhance the financial and political clout of the environmental sector in international politics. 


\section{United Nations Development Programme (UNDP)}

Although the United Nations Development Programme (UNDP) is neither by mandate nor in practice predominantly geared towards environmental protection, its financial importance for tackling associated issues at the project level is undeniable. In 2005, 11 percent of the Programme's \$3 billion portfolio were spent on projects under the label of "Energy and Environment", equalling \$326 million (UNDP 2006: 4) - which is more than UNEP's total funding for the same period. The UNDP dates back to a resolution adopted by the UN General Assembly in November 1965. It was given the mandate to assist capacity-building in developing countries with a view to pursuing key objectives, which today include poverty eradication, democratic governance, crisis prevention and recovery, and combating HIV/AIDS. With 3,300 staff located at headquarters in New York or in one of the Programme's 135 country offices, and with field activities in 166 countries, UNDP is the largest existing multilateral organisation for technical assistance and cooperation (Biermann and Bauer 2004: 7).

UNDP's environmental role is largely defined by its function as an implementing agency of associated global funding mechanisms, namely the issue-specific Montreal Protocol's Multilateral Fund or the cross-cutting Global Environment Facility (GEF). Receiving 30 percent of the former's funding, UNDP has supported the phasing out of ozonedepleting substances in developing countries through technical assistance, direct investment, feasibility studies and demonstration projects (DeSombre 2006: 115). UNDP's role in the GEF has so far seen the management of 1,750 projects in more than 155 developing countries. To finance such projects, in 2005 alone, UNDP secured $\$ 284.5$ million from the GEF, but also attracted \$1.02 billion in co-financing from governments and donors (UNDP 2006: 16). The environmental reputation of the Programme also rests upon renowned initiatives, for instance the Capacity 21 programme for storing and disseminating ecological data in developing countries, or the $\$ 1.7$ million MDG Carbon initiative, launched in February 2007, to install a pilot carbon trading scheme in China.

Due to these diverse and widespread field activities, UNDP has rightfully been praised as "a pragmatic complement to UNEP's global environmental treaty-making efforts", thereby promoting the idea of "mainstreaming", i.e. the integration of environmental concerns into its development agenda (WRI 2003: 144). However, this assessment needs to be balanced by considering ongoing inter-agency tensions and turf wars within the UN environmental machinery. Despite common projects with UNEP (e.g. the 2007 launch of the Poverty and Environment Facility to support Kyoto implementation in five African countries), observers have pointed to a historically grown lack of co-ordination which "pre-dates the integrative concept of sustainable development" (Biermann and Bauer 2004: 19). Given continuous internal reforms, a significant rise of non-core resources, and several shifts in environmental priorities over the last decade (ibid.: 9, 20), it remains to be seen to what extent the Programme can both follow its mainstreaming approach and achieve a better division of labour with UNEP. 


\section{World Bank}

A quite different approach to multilateral development assistance has been adopted by the World Bank. Unlike UNDP's grants-based assistance, the World Bank - as well as four regional multilateral development banks - supports projects with loans to be repaid. Moreover, the World Bank features a lower level of inclusion of developing countries and non-governmental organisations with regard to decision-making or disclosure of information. Since its establishment in 1944 under the name of "International Bank for Reconstruction and Development" (IBRD), the Bank has steadily expanded and today comprises a closely associated group of five development institutions with up to 185 members. Its mission has gradually evolved from post-war reconstruction in the early days to worldwide poverty alleviation - hence also touching upon environmental issues. In 2005, the Bank has spent $\$ 2.49$ billion on environmental and natural resource management, equalling 11 percent of its overall portfolio. ${ }^{4}$

Apart from this extensive lending for environmental projects, some of the Bank's success stories are owed to its capacity for "convening governments and setting guidelines" (WRI 2003: 143). Examples for this effective 'soft law' approach range from the initiation of a dialogue among logging industry leaders on sustainable forestry in 1998 to the "Equator Principles", i.e. environmental investment-guiding criteria based on World Bank standards. Another prominent case is the launch of a multi-stakeholder dialogue which led to the 1998 creation of the World Commission on Dams. The commission released principles and guidelines on future water and energy decision-making; notably, however, the principles were later rejected by the Bank's Board of Directors (ibid.: 170; Dingwerth 2005).

On the other hand, the Bank has attracted strong criticism for its contradictive agenda, mainly because some of its conventional projects (for instance the promotion of the use of fossil fuels) can severely undermine the positive results achieved with GEF funding (DeSombre 2006: 160). Critics have also pointed out that the Bank's lending policy is biased towards economic profit, which creates difficulties for many environmental projects on problems resulting from unpriced externalities (ibid.: 157). Moreover, the practice of drafting so-called Poverty Reduction Strategy Papers (PRSP) for recipient countries has been interpreted by UNDP as a redressed version of the Bank's highly controversial structural adjustment conditionalities (Biermann and Bauer 2004: 11).

\section{Global Environment Facility (GEF)}

Mistrust towards a potentially hidden conditionality has also accompanied another multilateral environmental financing institution: the Global Environment Facility. Having

\footnotetext{
${ }^{4}$ http://www.worldbank.org [03/04/2007]. This figure ranks even higher when accounting for environmental implications of other World Bank projects: while, in 2000, the Bank had officially spent $\$ 1.83$ billion on projects under the label of "environmental and natural resource management", the World Resources Institute assumes an overall portfolio of $\$ 5$ billion in environmental projects for the same year (WRI 2003: 152).
} 
been inspired by discussions in the World Bank, the Facility's pilot phase between 1991 and 1994 saw continuous tensions between developing countries and the United States over structural reforms (DeSombre 2006: 157). The result of these debates was a new type of international institution, "an amalgamation of traditional features of UN and Bretton Woods institutions" (Streck 2002: 130f.). As an open-ended funding mechanism for global environmental issues, the Facility is more transparent and democratic than the World Bank thanks to a double voting system, independent reviews and a significant participation of over 700 NGOs (WRI 2003: 153). Further distance to the World Bank was assured by designing GEF as a provider of grants - instead of loans - and by naming UNEP and UNDP as additional implementing agencies.

The Facility is mandated to finance incremental costs, i.e. new and additional funding which would not have been provided by other sources. This guideline has been criticised as failing to address "the underlying political causes of environmental degradation in developing countries" (DeSombre 2006: 160). This notwithstanding, between 1991 and 2004, the GEF allocated an impressive total of $\$ 6.8$ billion in grants, and could also leverage another $\$ 24$ billion in co-funding by governments, international organisations and private entities. With these resources, the Facility has supported over 1,900 projects in more than 160 developing countries and countries with economies in transition. ${ }^{5}$ More than half of this money was invested in the domains of the two Rio conventions - biodiversity loss and climate change followed by four other GEF focal areas: international waters, ozone depletion, land degradation and persistent organic pollutants.

The GEF deserves special credit for this allocation record. Furthermore, after its early restructuring, the Facility has undoubtedly become one of the most adaptive and transparent international institutions and displays a relatively high degree of North-South cooperation. Despite these achievements, it still has a difficult standing among some of its 177 members. Resistance to its work originates from both camps: whereas some of its sponsors have repeatedly failed to meet their funding obligations, some of the recipients resist the increasing scope of the Facility's activities and are unwilling to distribute funds among too many focal areas (DeSombre 2006: ibid.). In light of this opposition, some critics have voiced doubts about the Facility's innovative impulses. The GEF has to make considerable coordinative efforts in order to preserve a reasonably peaceful working relationship between implementing agencies and associated organisations - a role which does not grant much leeway for supporting experimental or cutting-edge projects. On a final cautionary note, whether or not specific projects can count as successes, the GEF's role has sometimes been criticised for 'greenwashing' the impact of the World Bank's ongoing investment practices (Young 2002).

\footnotetext{
${ }^{5}$ http://www.gefweb.org [03/04/2007].
} 


\section{World Trade Organization (WTO)}

\section{History}

As compared to the above institutions, the WTO is different in several regards: first of all, as a "related organisation" it is independent and hence far more detached from the UN system than programmes - such as UNEP or UNDP -, specialized agencies - such as the World Bank ${ }^{6}$ - or the GEF which is administered by the former three. Moreover, the WTO has no proactive environmental mandate, neither for financial nor technical assistance. Its environmental role is exerted in an ex post or indirect manner, which nonetheless has significant impact due to the organisation's considerable enforcement capacities.

This does not imply that environmental issues have not materialised in the organisation's structure or documents. In fact, sustainable development is recognised as a key objective in the preamble of the WTO agreement. And institutional arrangements date back to pre-WTO times: in November 1971, on the verge of the UNCHE conference, the General Agreement on Tariffs and Trade (GATT) established the Group on Environmental Measures and International Trade (EMIT) in order to account for the trade implications of environmental policies. Nonetheless, due to a lack of requests from the contracting parties, the EMIT never convened in the first twenty years after its establishment. It was thus only the late 1980s which saw a second environmental debate take place within the architecture of the GATT. This second debate "came at an awkward time for GATT signatories, since the Uruguay Round entered a deep crisis in the early 1990s and the agricultural dispute between the USA and the EU threatened to scupper the talks" (Santarius et al. 2004: 10). Though advocated by major industrialized countries, any comprehensive approach to ecological standards was blocked by developing countries who interpreted them as a disguise for protectionist measures (Eglin 1998: 252).

\section{Structure and Activities}

The major institutional manifestation of the WTO's environmental role is the Committee on Trade and Environment (CTE). The committee has a standing agenda and includes all current 150 WTO members as well as several observers from intergovernmental organisations (but not from NGOs) who gather at least two times a year for formal meetings plus further informal ones if needed. Its chief mandate is to ensure a positive interaction between trade and environment measures inside and outside WTO law - and to recommend appropriate modifications to the latter where necessary. The CTE is supported by the WTO Secretariat's Trade and Environment Division which provides technical assistance to WTO members, reports to them about discussions in other intergovernmental organisations and maintains contact with non-governmental actors.

Despite these bodies and their mandates, it is not accurate to speak of a proper WTO environmental policy. The Trade and Environment Division is merely performing a service

\footnotetext{
6 Specialised agencies are autonomous organisations working with the UN through ECOSOC (http://www.un.org/aboutun/ [03/03/2007]).
} 
function while the WTO Secretariat has not been endowed with any competency to set its own environmental agenda (Bernauer 1999: 132f.). Similarly, the CTE is anything but pro-active on ecological matters: first of all, the committee's mandate is not to tackle free trade's impact on the environment; instead, it is supposed to act under exactly reversed premises and address the effects of environmental measures on trade policy (Santarius et al. 2004: 48). Second, the CTE does not consist of independent agents but of governmental representatives and its reports rest upon consensual decision-making. This lack of environmental momentum from within the WTO was desired by its creators, bearing justice to concerns voiced by developing countries who feared a 'green' conditionality for market access.

Given these intended shortcomings, the environmental agenda of the WTO is mostly shaped through a different channel: via the conflict of WTO law with domestic and international environmental regulations, and via the respective judicial interpretation and settlement of these conflicts (cf. Zelli 2006). In terms of quantity, the WTO Dispute Settlement Body (DSB) has constantly broadened its ecological agenda over the years through decisions on topics ranging from species protection via air pollution to consumer and health standards. This development mirrors the general extension of jurisdictional scope during the transition from GATT to WTO: today, no less than 60 legal instruments under the auspices of the WTO cover a multitude of different policy fields, from agriculture to labour rights or from international finance to telecommunications (cf. Sampson 2005: 128ff.). The DSB and its two-layered system - consisting of the Panel and the Appellate Body (AB) cannot issue reports on their own initiative, but the member states can invoke the DSB in order to block the implementation of other countries' ecological policies. Hence, the DSB substantially differs from the WTO's political bodies because it is not caught in a stalemate among countries and can reach final decisions through independent procedures.

In terms of substance and quality, one can observe an increasing tendency towards more flexible and integrative decisions. This concerns two key types of contested environmental standards: on the one hand, the precautionary principle, for instance addressed in a famous case on beef treated with hormone growth promoters (1998); and, on the other hand, provisions related to production methods, for example the US import bans based on fishing methods. Such non-trade preoccupations have gradually become integrated into the decisions - either through demands for multilateral negotiations and agreements in order to specify WTO law (as in the 1998 US - Shrimp report) ${ }^{7}$ or through the recognition of the actual objectives of trade-restrictive measures (especially health issues, as in the $E C$ Asbestos decision). However, given increasing protests by WTO members about the Appellate Body's flexible interpretation of the agreement (Sampson 2002: 23), only time will tell whether this tendency towards more environmentally sound rulings will prevail.

\footnotetext{
${ }^{7}$ These decisions were partly based on "general exceptions" which two WTO agreements grant for measures protecting human, animal or plant life or conserving natural resources (Article XX GATT and Article XIV GATS [General Agreement on Trade in Services]).
} 
Apart from these conflicts over domestic environmental regulations, a number of noteworthy overlaps exist between WTO law and multilateral environmental agreements (MEAs). Some of the trade-related measures of the Montreal Protocol on ozone depletion, for instance, collide with the WTO principle of most favoured nation treatment "by banning the import of various substances on the basis of the status of the country of origin" (Werksman 2001: 183). Moreover, the Kyoto Protocol might get into conflict with WTO law on a number of aspects, one of them being its constraints on the trade in carbon emissions (Chambers 2001: 103).

\section{Evaluation}

It is crucial to deny the merely theoretical character of WTO-MEA conflicts on two grounds: first, the current lack of legal disputes may be due to the fact that the majority of the MEAs in question have only been adopted within the last 15 years, and some of them have either not yet or only recently entered into force. Second, although there are no judicial controversies, the shadow of WTO law and its strong dispute settlement system may well provoke anticipatory conflicts or "chilling effects" (Stillwell and Tuerk 1999, Eckersley 2004), whereby MEA negotiators refrain from specifying more ambitious trade-relevant measures or face a country's refusal to ratify an agreement or protocol (Pauwelyn 2003: 237ff.).

At present, any solution or regulation of these conflicts and overlaps between WTO law and domestic or international environmental rules seems improbable. There have been several initiatives, including a 1999 cooperation agreement among WTO and UNEP secretariats which launched a regular exchange of information on legal issues. Moreover, a "trade and environment" section has been included in the WTO's 2001 Doha Declaration. Article 32 extended the CTE's mandate towards "the effect of environmental measures on market access", the environmentally relevant provisions of the TRIPS Agreement and "labelling requirements for environmental purposes". Pursuant to this explicit request for compatibility, a CTE Special Session (CTESS) was to discuss a number of models for harmonizing WTO law and the trade-related measures of MEAs. However, mirroring the overall crisis of the Doha Round, the first CTESS as well as its follow-up meetings - e.g. on the liberalisation of environmental goods and services - have stimulated little agreement among WTO members on the further coordinative process.

\section{Other International Organisations in Global Environmental Governance}

The previous sections have introduced major, globally operating international organisations and bodies which either have an environmental mandate or have otherwise exerted significant influence on environmental issues and policies. With the exception of the WTO, all of these organisations represent core components or affiliated institutions of the United Nations system. In addition, Table 1 lists a number of further international organisations engaged in 
environment-related activities. ${ }^{8}$ Not surprisingly, these are also related to the UN. All but the last two have the status of a specialised agency (i.e. of an autonomous organisation working with the UN).

\begin{tabular}{|c|c|c|c|}
\hline Organization & Est. & Function & Website \\
\hline $\begin{array}{l}\text { Food and Agriculture } \\
\text { Organization of the United } \\
\text { Nations (FAO) }\end{array}$ & 1945 & $\begin{array}{l}\text { FAO is the lead UN agency responsible for assessing } \\
\text { the state of global agriculture, forests, fisheries, and for } \\
\text { promoting sustainable development and harvest of these } \\
\text { resources. }\end{array}$ & www.fao.org \\
\hline $\begin{array}{l}\text { United Nations } \\
\text { Educational, Scientific and } \\
\text { Cultural Organization } \\
\text { (UNESCO) }\end{array}$ & 1945 & $\begin{array}{l}\text { UNESCO promotes collaboration among nations } \\
\text { through education, science, culture, and communication } \\
\text { in order to further universal respect for justice, for the } \\
\text { rule of law, and for human rights. }\end{array}$ & "www.unesco.org \\
\hline $\begin{array}{l}\text { United Nations Industrial } \\
\text { Development } \\
\text { Organization (UNIDO) }\end{array}$ & 1966 & $\begin{array}{l}\text { UNIDO works to strengthen industrial capacities of } \\
\text { developing and transition nations with an emphasis on } \\
\text { promoting cleaner and sustainable industrial processes. }\end{array}$ & www.unido.org \\
\hline $\begin{array}{l}\text { International Atomic } \\
\text { Energy Agency (IAEA) }\end{array}$ & 1957 & $\begin{array}{l}\text { The IAEA serves as an intergovernmental forum for } \\
\text { scientific and technical cooperation in the peaceful use } \\
\text { of nuclear technology, promoting nuclear safety and } \\
\text { non-proliferation. }\end{array}$ & www.iaea.org \\
\hline $\begin{array}{l}\text { International Maritime } \\
\text { Organization (IMO) }\end{array}$ & 1948 & $\begin{array}{l}\text { The IMO is responsible for improving maritime safety } \\
\text { and preventing pollution from ships. }\end{array}$ & www.imo.org \\
\hline $\begin{array}{l}\text { World Health } \\
\text { Organization (WHO) }\end{array}$ & 1948 & $\begin{array}{l}\text { The WHO catalyzes international cooperation for } \\
\text { improved health conditions, including a health } \\
\text { environment. }\end{array}$ & www.who.int \\
\hline $\begin{array}{l}\text { World Meteorological } \\
\text { Organization (WMO) }\end{array}$ & 1950 & $\begin{array}{l}\text { The WMO coordinates scientific efforts in global } \\
\text { weather forecasting and conducts research on air } \\
\text { pollution, climate change, ozone depletion, and tropical } \\
\text { storms. }\end{array}$ & www.wmo.ch \\
\hline $\begin{array}{l}\text { United Nations Population } \\
\text { Fund (UNFPA) }\end{array}$ & 1969 & $\begin{array}{l}\text { The UNFPA assists countries in providing reproductive } \\
\text { health and family planning services, formulates } \\
\text { population strategies, and advocates for issues related to } \\
\text { population, reproductive health, and the empowerment } \\
\text { of women. }\end{array}$ & "www.unfpa.org \\
\hline $\begin{array}{l}\text { Intergovernmental Panel } \\
\text { on Climate Change } \\
\text { (IPCC) }\end{array}$ & 1988 & $\begin{array}{l}\text { The IPCC was established under the auspices of UNEP } \\
\text { and the WMO to assess scientific, technical, and socio- } \\
\text { economic information relevant for the understanding of } \\
\text { climate change, its potential impacts, and options for } \\
\text { adaptation and mitigation. }\end{array}$ & www.ipcc.ch \\
\hline
\end{tabular}

\footnotetext{
${ }^{8}$ The authors are grateful to the World Resources Institute for the permission to reprint this table. It first appeared (in a longer version) as 'Table 7.1: Selected Intergovernmental Organizations that Influence Environmental Governance' in World Resources 2002-2004 - Decisions for the Earth: Balance, Voice, and Power (WRI 2003: 142-43). The section on the WMO has been added by us.
} 


\section{Conclusions}

The international bodies and agencies which have been portrayed in this chapter differ with regard to several dimensions, including the breadth of their mandate (environmental protection, sustainable development, or non-environmental issues) as well as their agenda and predominant policy approach (funding, technical assistance, rule setting or rule enforcement, etc.). Another distinctive criterion is the position of these organisations with respect to the United Nations; it is intriguing that - with the exception of the WTO - all of them are somehow linked to the UN system, albeit in different roles. Hence the observed variety of organisations in global environmental governance is mostly rooted in the complexity of the UN environmental machinery which, in turn, "reflects the complexity and diversity of environmental issues themselves" (WRI 2003: 141). This observation notwithstanding, one should not judge this decentralised arrangement as an inevitable necessity, let alone welcome it as an overtly harmonious "symphony" of organisations (ibid.: 139). For sure, the variety of platforms has produced numerous benefits, among them: raising awareness and generating information on a range of environmental problems and policies, mobilising expertise from scientists and NGOs, providing international negotiating fora, making significant contributions to international environmental law, and building capacities to implement environmental policies in the developing world (ibid.: 141ff.).

Yet, on the other hand, the institutional fragmentation implies overlapping mandates and, more importantly, it entails considerable shortcomings in coordination: more often than not, the various institutions have restricted cooperation to a well-defined number of issues, and inter-agency 'turf battles' over competencies and resources are a constant occurrence. Most prominently, "other UN bodies have refused to accept UNEP's mandate to coordinate all environmental activities in the UN system due to 'institutional seniority.' A number of UN agencies [...] possessed environmental responsibilities before UNEP was created and thus feel less of a need to defer to UNEP" (Ivanova 2005: 25). Apart from the high transaction costs arising from such institutional incoherence, this patchwork is not capable of playing the role of a strong advocate for global environmental concerns vis-à-vis governments or nonenvironmental organisations. As a result, the various bodies of the UN environmental machinery have to compete for scarce contributions from national governments, while failing to convince other organisations to open their portfolios more extensively for environmental concerns.

Thus, the two ongoing debates on global environmental governance we mentioned at the outset of this chapter - fragmentation vs. centralisation and sectoralisation vs. mainstreaming - are clearly interrelated. Merging both discussions has inspired calls for a centralised and cross-cutting World Sustainable Development Organization, or, with less mainstreaming zeal, for a UN Environment Organisation - a centralised, but issue-specific authority (Biermann and Bauer 2006). This chapter has implicitly made a similar case, by sketching the strong impact of the world trade regime on a largely toothless mosaic of environmental institutions and regulations. However, the section on the WTO has also 
revealed that creating a centralised counterweight is no reliable panacea. The WTO itself has repeatedly been dogged by conflict among its member states, quite similar to the stalemates which keep undermining the coordination among multilateral environmental organisations. The real difference is the WTO's strong dispute settlement mechanism which can temporarily circumvent such standstill and exerts an unprecedented influence on domestic and international policies. Thus, in order to play an effective role in "Earth system governance" (Biermann 2007), a future world environment organisation would need to be endowed with comparable dispute settlement and enforcement capacities.

Meanwhile, on a less ambitious but more realistic scale, international environmental organisations should try to maximise the synergistic potentials of their overlapping tasks. They could do so through enhanced mainstreaming and division of labour at the project level, and through bolder cooperation agreements at the organisational level. In addition, striving for cross-issue package deals among country coalitions might break negotiation impasses within and between organisations: governments could more actively link environmental issues with non-environmental concerns - especially with issues of "high politics" such as security or trade. Undoubtedly, such integrative or mainstreaming attempts will have to walk a thin tightrope: improving inter-organisational coordination while making sure that the environmental component is not diluted or absorbed by other concerns.

\section{Bibliography}

Bennett, A. L. and J. K. Oliver. 2002. International Organizations: Principles and Issues. Upper Saddle River: Prentice Hall.

Bernauer, T. 1999. Handelsliberalisierung und Umweltschutzpolitik: Konflikte und Synergien. In Handel und Umwelt: zur Frage der Kompatibilität internationaler Regime, eds. Bernauer, T. Bernauer and D. Ruloff, 118-140. Opladen, Germany: Westdeutscher Verlag.

Biermann, F. 2007 (forthcoming). 'Earth System Governance' as a Crosscutting Theme of Global Change Research. Global Environmental Change, 17.

Biermann, F. and S. Bauer. 2004. United Nations Development Programme (UNDP) and United Nations Environment Programme (UNEP). Berlin, Germany: WBGU. URL = http://www.wbgu.de/wbgu_jg2004_ex02.pdf [03/04/2007]. 
Biermann, F. and S. Bauer. eds. 2005: A World Environment Organization: Solution or Threat for Effective International Environmental Governance? Aldershot, UK: Ashgate.

Bigg, T. 2003. The World Summit on Sustainable Development: Was it worthwhile?

International Institute for Environment and Development (IIED). URL = http://www.poptel.org.uk/iied//docs/wssd/wssdreview.pdf [03/04/2007].

Chambers, W. B. 2001. International trade law and the Kyoto Protocol: potential incompatibilities. In Inter-linkages: the Kyoto Protocol and the International Trade and Investment Regimes, ed. W. B. Chambers, 87-118. Tokyo, Japan: United Nations University Press.

Chasek, P. 2000. Introduction: the global environment at the dawn of a new millennium. In The Global Environment in the Twenty-First Century: Prospects for International Cooperation, ed. P. Chasek, 1-11. New York: The United Nations University Press.

Conca, K. 1995. Greening the United Nations: environmental organisations and the UN system. Third World Quarterly, 16 (3): 441-457.

D'Anieri, P. 1995. International Organizations, Environmental Cooperation, and Regime Theory. In International Organizations and Environmental Policy, eds. R. V. Bartlett, P. A. Kurian, and M. Malik, 153-169. Westport: Greenwood Press.

DeSombre, E. R. 2006. Global Environmental Institutions. London, UK: Routledge.

Dingwerth, K. 2005. The Democratic Legitimacy of Public-Private Rule Making: What Can We Learn from the World Commission on Dams? Global Governance,11 (1): 65-83

Downie, D. L. 1995. UNEP and the Montreal Protocol. In International Organizations and Environmental Policy, eds. R. V. Bartlett, P. A. Kurian, and M. Malik, 171-185. Westport: Greenwood Press.

Downie, D. L. and M. A. Levy. 2000. The UN Environment Programme at a Turning Point: Options for change. In The Global Environment in the Twenty-First Century: Prospects for International Cooperation, ed. P. Chasek, 355-377. New York: The United Nations University Press.

Eckersley, R. 2004. The Big Chill: The WTO and Multilateral Environmental Agreements. Global Environmental Politics, 4 (2): 24-40.

Eglin, R. 1998. Trade and environment. In The Uruguay Round and beyond: Essays in Honour of Arthur Dunkel, eds. J. Bhagwati, J. and M. Hirsch, 251-263. Berlin, Germany: Springer.

Imber, M. F. 1996. The Environment and the United Nations. In The Environment and International Relations, eds. J. Vogler and M. F. Imber, 138-151. London \& New York: Routledge.

Ivanova, M. 2005. Can the Anchor Hold? Rethinking the United Nations Environment Programme for the $21^{\text {st }}$ Century. Yale F\&ES Publication Series, Report No. 7. URL= 
http://environment.yale.edu/documents/downloads/o-u/report_7_unep_evaluation.pdf [03/04/2007].

Karns, M. P. and K. A. Mingst. 2004. International Organizations: The Politics and Processes of Global Governance. Boulder \& London: Lynne Rienner.

Keohane, R. O. 1989. International Institutions and State Power: Essays in International Relations Theory. Boulder: Westview Press.

Pauwelyn, J. 2003. Conflict of Norms in Public International Law: How WTO Law Relates to Other Rules of International Law. Cambridge, UK: Cambridge University Press.

Sampson, G. P. 2002. The World Trade Organization and Global Environmental Governance. Tokyo, Japan: United Nations University Press.

Sampson, G. P. 2005. The WTO and Sustainable Development. Tokyo, Japan: United Nations University Press.

Santarius, T., H. Dalkmann, M. Steigenberger, K. Vogelpohl. 2004. Balancing Trade and Environment: an Ecological Reform of the WTO as a Challenge in Sustainable Global Governance, Wuppertal Paper No. 133e, Wuppertal, Germany: Wuppertal Institute for Climate, Environment and Energy. URL= http://www.wupperinst.org/globalisierung/pdf_global/balancing_trade.pdf [03/04/2007].

Stilwell, M. and E. Tuerk. 1999. Trade Measures and Multilateral Agreements: Resolving Uncertainty and Removing the WTO Chill Factor. WWF International Discussion Paper, November 1999.

Streck, C. 2002. Global Public Policy Networks as Coalitions for Change. In Global Environmental Governance. Options \& Opportunities, eds. D. C. Esty and M. H. Ivanova, 121-139. New Haven, CT: Yale School of Forestry \& Environmental Studies.

Thomas, U. O. 2004. UNEP 1972-1992 and the Rio Conference. EcoLomic Policy and Law: Journal of Trade and Environment Studies, 4 (Special Issue).

UNDP (United Nations Development Programme). 2006. Global Partnership for Development. UNDP Annual Report 2006. New York, NY: UNDP. http://www.undp.org/publications/annualreport2006/english-report.pdf [03/04/2007].

UNEP (United Nations Environment Programme). 2007. UNEP 2006 Annual Report. Nairobi, Kenya: UNEP. URL= http://www.unep.org/pdf/annualreport/UNEP_AR_2006_English.pdf [03/04/2007].

Vogler, J. 2007. The International Politics of Sustainable Development. In Handbook of Sustainable Development, eds. G. Atkinson, S. Dietz and E. Neumayer, 430-446.

Cheltenham: Edward Elgar.

Von Frantzius, I. 2004. World Summit on Sustainable Development Johannesburg 2002: A Critical Analysis and Assessment of the Outcomes. Environmental Politics, 13 (2): 467-473. 
Wagner, L. M. 2005. A commission will lead them? The UN commission on sustainable development and UNCED follow-up. In Global Challenges: Furthering the Multilateral Process for Sustainable Development, eds. A. C Kallhauge, G. Sjöstedt and E. Corell, 103122. Sheffield: Greenleaf.

Werksman, J. 2001. Greenhouse-gas emissions trading and the WTO. In Inter-linkages: the Kyoto Protocol and the International Trade and Investment Regimes, ed. W. B. Chambers, 153-190. Tokyo, Japan: United Nations University Press.

WRI (World Resources Institute) 2003. World Resources 2002-2004 - Decisions for the Earth: Balance, Voice, and Power. Report produced in collaboration with UNDP, UNEP, and the World Bank. Washington, DC: WRI.

Young, Z. 2002. A New Green Order? The World Bank and the Politics of the Global Environment Facility. London: Pluto Press.

Zelli, F. 2006. The World Trade Organization: Free Trade and its Environmental Impacts. In Handbook of Globalization and the Environment, eds. K.V. Thai, D. Rahm and J. D. Coggburn, 177-216. London, UK: Taylor \& Francis. 